\title{
ANALISIS KANDUNGAN LOGAM KADMIUM (Cd) DALAM AIR MINUM ISI ULANG (AMIU) DI KOTA LHOKSEUMAWE, ACEH
}

\author{
Ahmad Fikri Pulungan ${ }^{1}$, Sri Wahyuni ${ }^{1^{*}}$ \\ ${ }^{1}$ Prodi Kedokteran, Fakultas Kedokteran Universitas Malikussaleh \\ *Corresponding Author: sri.wahyuni@unimal.ac.id
}

\begin{abstract}
Abstrak
Air minum sangat penting untuk kesehatan manusia karena berhubungan langsung dengan proses biologis tubuh. Depot air minum isi ulang adalah usaha pengolahan air baku menjadi air minum dalam bentuk curah dan dijual langsung kepada konsumen. Air Minum Isi Ulang (AMIU) dapat terkontaminasi oleh logam berat seperti kadmium akibat dari aktivitas manusia dan proses alami lingkungan. Kadmium adalah logam berat yang berbahaya karena bersifat non-degradable dalam tubuh organisme hidup dan memiliki efek toksik bagi tubuh walau dalam kadar yang sangat rendah. Akumulasi kronis Cd dapat mengakibatkan kerusakan tubular ginjal dan kanker. Jenis penelitian ini bersifat deskriptif dengan uji laboratorium. Kandungan $\mathrm{Cd}$ diukur dengan Atomic Absorption Spectrophotometry melalui metode SSA-Flame. Sebanyak 46 sampel air diambil dari depot yang tersebar di 4 Kecamatan di Kota Lhokseumawe. Data kadar Cd dibandingkan dengan Permenkes RI No. 492/Menkes/Per/IV/2010 (< $0,003 \mathrm{mg} / \mathrm{l})$. Nilai maksimum kadar $\mathrm{Cd}$ adalah $0,004 \mathrm{mg} / \mathrm{l}$ serta nilai minimum yang didapat adalah $0,001 \mathrm{mg} / \mathrm{l}$. Rerata kadar Cd adalah 0,0019 $\pm 0,00072 \mathrm{mg} / 1 \mathrm{dan} \mathrm{masih}$ dalam batas yang ditetapkan. Namun, terdapat 1 (satu) AMIU melebihi ambang batas kadar kadmium yaitu $0,004 \mathrm{mg} / \mathrm{l}$. Penelitian ini menyimpulkan bahwa rerata kadar masih dalam batas yang ditetapkan.
\end{abstract}

Kata Kunci: Kadmium; air minum isi ulang; Atomic Absorption Spectrophotometry

Cadmium analysis in refill drinking water in Lhokseumawe City, Aceh

\begin{abstract}
Drinking water is vital for human health because it is directly related to the human body's biological processes. Refill drinking water depot supplies raw water into drinking water in bulk form and sells directly to consumers. Heavy metals like Cadmium can contaminate refill drinking water due to human activities and natural environmental processes. Cadmium is a dangerous heavy metal because it is nondegradable by living organisms and affects the human body even at very low levels. Chronic accumulation of $\mathrm{Cd}$ leads to kidney tubular damage and cancer. This descriptive study with laboratory analysis was aimed to determine the Cd level in forty-six samples of refill drinking water samples distributed in four sub-districts in Lhokseumawe city, Aceh. The Cadmium level was analyzed by Atomic Absorption Spectrophotometry with SSA-Flame method. The data were compared to the Indonesia Health Ministry Regulation (2010). The minimum and maximum level of $\mathrm{Cd}$ were $0,001 \mathrm{mg} / 1$ and $0,004 \mathrm{mg} / 1$, respectively. Mean value of Cadmium was 0,0019 $\mathrm{mg} / \mathrm{l} \pm 0,00072 \mathrm{mg} / \mathrm{l}$, however one sample has concentration more than regulatory
\end{abstract}


threshold $(0,004 \mathrm{mg} / \mathrm{l})$. After comparing the data to the permissible limit, the study revealed that $\mathrm{Cd}$ level in refill drinking water concentration was within the regulatory threshold.

\section{Keywords: Cadmium; refill drinking water; Atomic Absorption Spectrophotometry}

\section{Pendahuluan}

Air sangat penting untuk kebutuhan manusia untuk menjaga kesegaran dan kebugaran jasmani. Air minum tidak kalah pentingnya dengan unsur gizi seperti karbohidrat, protein, lemak, dan vitamin. Konsumsi air minum yang baik dan cukup bagi tubuh adalah sebanyak 12,5 liter atau setara dengan 6-8 gelas setiap harinya, sehingga dapat membantu proses pencernaan, mengatur metabolisme, mengatur zat-zat makanan dalam tubuh dan mengatur keseimbangan tubuh. ${ }^{1}$

Air minum langsung berhubungan dengan proses biologis tubuh sehingga air minum memerlukan persyaratan yang ketat. Air minum harus memenuhi persyaratan yang telah ditetapkan oleh Kementerian Kesehatan RI. Tubuh manusia terdiri dari 70\% air dan lebih dari 90\% proses biokimia tubuh menggunakan air sebagai mediumnya. Air minum harus berkualitas baik agar tidak mengganggu proses biokimiawi dalam tubuh manusia dan fungsionalnya. ${ }^{2}$ Parameter wajib dan parameter tambahan dari persyaratan kualitas air minum meliputi persyaratan kimia, mikrobiologi, fisik dan radioaktivitas. Air minum tidak boleh mengandung senyawa kimia beracun dan tiap zat terlarut mempunyai batas tertentu yang diperbolehkan terkandung dalam air. Air minum dapat menyehatkan, namun dapat juga berpotensi sebagai media penularan penyakit dan penyebab terjadinya keracunan. ${ }^{3}$

Kebutuhan air minum semakin lama semakin meningkat sehingga muncul berbagai usaha air minum baik air minum dalam kemasan (AMDK), maupun air minum isi ulang atau biasa disingkat AMIU. Harga AMDK masih relatif mahal sehingga masyarakat mulai mencari alternatif pilihan air minum baru. Beberapa alasan air minum isi ulang dari depot air minum menjadi salah satu pilihan karena mudah didapatkan, praktis, tidak perlu dimasak terlebih dahulu, dan harganya sangat terjangkau. Pembelian AMIU juga cukup mudah, konsumen datang dengan membawa galon bekas dari merek apa saja untuk isi ulang ke depot air minum atau dapat memanfaatkan layanan antar jemput. ${ }^{4}$

Salah satu faktor yang berperan dalam menentukan derajat kesehatan masyarakat yang optimal adalah lingkungan. Air bersih merupakan salah satu Standar Baku Mutu Kesehatan Lingkungan dan Persyaratan Kesehatan dari media lingkungan. Untuk mendukung kesehatan 
lingkungan dan masyarakat, tiap rumah tangga harus memiliki akses air minum yang layak dan bersih.

Riskesdas tahun 2017 melaporkan secara nasional persentase rumah tangga dengan akses air minum yang layak tertinggi berturut-turut adalah Bali (72,04\%), DKI Jakarta (88,93\%), dan Kepulauan Riau (83,95\%). Sedangkan persentase untuk provinsi Aceh sebesar 64,85\%. Target Renstra Kementerian Kesehatan (2017) adalah 40\% dari sarana air minum harus dilakukan pengawasan, tetapi provinsi Aceh hanya mencapai 7,04\%. Terdapat sepuluh provinsi yang telah memenuhi target Renstra tersebut. Pengawasan kualitas air minum diatur oleh Peraturan Menteri Kesehatan Nomor 736 tahun 2010 tentang Tata Laksana dan Pengawasan Kualitas Air Minum memutuskan bahwa pengawasan internal dilakukan oleh penyelenggara air minum komersial, sedangkan pengawasan eksternal dilakukan oleh Dinas Kesehatan Kabupaten/Kota terkait. ${ }^{5}$

Air minum depot isi ulang dapat tercemar oleh kandungan kadar logam yang melampaui ambang batas normal, sehingga tidak semua air minum isi ulang terjamin keamanannya. Badan Pengawas Obat dan Makanan Republik Indonesia (BPOM RI) telah menguji mutu produksi dari 95 depot air minum isi ulang di 5 kota. Sebanyak 9 (sembilan) produk mengandung kadmium $(\mathrm{Cd})$ yang melebihi batas yang ditetapkan. ${ }^{6}$ Kadar logam yang melampaui ambang batas normal ini dapat berbahaya bagi kesehatan konsumen. ${ }^{7}$

Kualitas air tanah di suatu lingkungan dipengaruhi oleh aktivitas manusia, tingkat curah hujan, dan proses alami dari lingkungan tersebut. ${ }^{8}$ Logam berat kadmium $(\mathrm{Cd})$ bersifat toksik dan dapat mengkontaminasi air tanah dan perairan. Logam $\mathrm{Cd}$ ini memasuki lingkungan perairan akibat dari aktivitas manusia (antropogenik). ${ }^{9}$ Kadmium dapat masuk ke dalam air minum melalui penetrasi air limbah industri yang mengandung $\mathrm{Cd}$ ke dalam distribusi air dan juga melalui tabung dan wadah polietilen. ${ }^{10}$

Kadmium (Cd) bersifat toksik bagi tubuh walaupun dalam kadar yang sangat rendah. Efek toksik Cd dipengaruhi oleh lama paparan dan kadar selama paparan, sehingga jika terpapar dengan kadar yang tinggi dalam waktu lama akan meningkatkan efek toksik yang lebih besar. Dosis tunggal Cd dapat menyebabkan gangguan saluran pencernaan, sedangkan paparan $\mathrm{Cd}$ dalam dosis rendah tetapi berulang kali bisa menyebabkan gangguan fungsi ginjal. ${ }^{11}$ Akibat mudahnya terakumulasi baik dalam sedimen maupun organisme, Cd dapat mengakibatkan gangguan sistem biologis. Kadmium merupakan salah satu jenis logam berat yang berbahaya karena bersifat non-degradable oleh organisme hidup. ${ }^{9}$

Organ tubuh seperti ginjal dan hati adalah target keracunan $\mathrm{Cd}$. Kandungan $\mathrm{Cd}$ sebanyak $200 \mu \mathrm{g}$ (berat basah) dalam cortex ginjal dapat mengakibatkan kegagalan ginjal 
berujung pada kematian. Penimbunan $\mathrm{Cd}$ dalam tubuh meningkat sesuai usia yaitu paruhumur pada rentang waktu 20-30 tahun dalam tubuh. ${ }^{12}$ Penyakit lain seperti lumbago yang dapat disebabkan oleh keracunan Cd juga telah terjadi di Jepang yang berlanjut dengan kerusakan tulang akibat melunak dan retaknya tulang. ${ }^{13}$ Selain itu, Cd juga sudah diklasifikasikan sebagai agen karsinogenik oleh International Agency for Research on Cancer (ICRP). ${ }^{14}$

Peraturan Menteri Kesehatan Republik Indonesia No. 492/MENKES/PER/IV/2010 telah mengatur batasan logam berat yang terdapat di air minum. Logam berat $\mathrm{Cd}$ termasuk dalam parameter wajib dan parameter yang langsung berhubungan dengan kesehatan. Batasan standar yang diatur oleh WHO dan EPA untuk kandungan Cd pada air minum adalah 3 dan 5 $\mu \mathrm{g} /$. $^{15}$

\section{Metode}

Penelitian deskriptif laboratorik ini berlokasi di Kota Lhokseumawe, Aceh. Populasi penelitian ini adalah seluruh depot air minum isi ulang di Kota Lhokseumawe yang terbagi atas 4 Kecamatan yaitu Kecamatan Muara Dua, Kecamatan Muara Satu, Kecamatan Blang Mangat dan Kecamatan Banda Sakti. Sampel akan diambil dengan menggunakan teknik cluster sampling dengan sampel minimal adalah 46 sampel air minum isi ulang. Berdasarkan cluster sampling, maka sebanyak 15 sampel di Kecamatan Muara Dua, 8 depot di Kecamatan Muara Satu, 5 depot di Kecamatan Blang Mangat dan 18 depot di Kecamatan Banda Sakti. Kandungan Cd diukur dengan Atomic Absorption Spectrophotometry melalui metode SSAFlame. Pemeriksaan untuk mengetahui nilai ambang batas $\mathrm{Cd}$ menggunakan peraturan Permenkes tahun 2010 dengan nilai tidak melewati ambang batas $(\leq 0,003 \mathrm{mg} / \mathrm{l})$ atau melewati ambang batas $(>0,003 \mathrm{mg} / \mathrm{l})$.

\section{Hasil}

Sumber air baku AMIU yang digunakan didapat dari hasil wawancara yaitu 21 berasal dari air Perusahaan Daerah Air Minum (PDAM), 14 dari Air sumur, 10 dari sumber air PT. Pupuk Iskandar Muda (PIM) dan 1 sumber air berasal dari PT. ARUN.

Berdasarkan Permenkes 2010, terdapat 45 AMIU yang mengandung Cd tidak melewati ambang batas (98\%) dan terdapat 1 (2\%) AMIU yang mengandung Cd melewati ambang batas. Sampel air minum isi ulang yang mengandung Cd tertinggi terdapat di Kecamatan Muara Satu dengan kadar Cd 0,004 mg/l dengan air baku bersumber dari air PT. PIM. Kadar Cd yang melebihi ambang batas menandakan tidak aman untuk dikonsumsi. 
Nilai rata-rata hasil kadar Cd adalah 0,00019 mg/l. Nilai tengah kadar Cd 0,0019 mg/1 kemudian nilai standar deviasi yang didapat yaitu 0,00072. Nilai maksimum kadar Cd adalah $0,004 \mathrm{mg} / 1$ serta nilai minimum yang didapat adalah $0,001 \mathrm{mg} / \mathrm{l}$.

Tabel 1. Nilai rerata dan standar deviasi kadar Cd di setiap Kecamatan Kota Lhokseumawe

\begin{tabular}{lcc}
\hline \multicolumn{1}{c}{ Kecamatan } & Rerata (mg/l) & Standar deviasi (mg/l) \\
\hline Muara Dua & 0,0015 & 0,00046 \\
Banda Sakti & 0,0018 & 0,00071 \\
Muara Satu & 0,0026 & 0,0026 \\
Blang Mangat & 0,002 & 0,00071 \\
\hline
\end{tabular}

Tabel 1 menunjukkan nilai rata-rata hasil kadar Cd di Kecamatan Muara Dua 0,0015 mg/l, Kecamatan Banda Sakti 0,0018 mg/l, Kecamatan Muara Satu 0,0026 mg/l, Kecamatan Blang Mangat 0,002 mg/l. Nilai rata-rata kadar $\mathrm{Cd}$ berdasarkan sumber air baku adalah PDAM 0,002 mg/l, air sumur 0,0016 mg/l, PT.PIM 0,0022 mg/l, PT. ARUN 0,002 mg/1 ditampilkan dalam tabel 3.

Tabel 2. Hasil kadar Cd berdasarkan Permenkes

\begin{tabular}{lcc}
\hline & Jumlah & Persentase (\%) \\
\hline Tidak melewati ambang batas $(\leq 0,003 \mathrm{mg} / \mathrm{l})$ & 45 & 98 \\
Melewati ambang batas $(>0,003 \mathrm{mg} / \mathrm{l})$ & 1 & 2 \\
\hline
\end{tabular}

Tabel 2 menunjukkan bahwa 1 dari 46 sampel AMIU tidak memenuhi syarat ambang batas yang diperbolehkan permenkes.

Tabel 3. Nilai rerata dan standar deviasi kadar Cd berdasarkan sumber air baku

\begin{tabular}{lc}
\hline Sumber air baku & Rerata $(\mathbf{m g} / \mathbf{l})$ \\
\hline PDAM & 0,002 \\
Air sumur & 0,0016 \\
PT. PIM & 0,0022 \\
PT. ARUN & 0,002 \\
\hline
\end{tabular}

\section{Pembahasan}

Pemeriksaan Cd dengan menggunakan spektrofotometri menunjukkan kadar Cd yang bervariasi. Kadar Cd tertinggi terdapat di Kecamatan Muara Satu dengan kadar 0,004 mg/1 
dan sudah melewati ambang batas maksimum Cd menurut Permenkes tahun 2011. Penelitian Nurul et al (2019) di lingkungan sekitar Universitas Islam Indonesia Yogyakarta menemukan bahwa 2 dari 3 sampel yang diteliti mengandung kadar $\mathrm{Cd}$ melebihi ambang batas yaitu $0,0083 \mathrm{mg} / \mathrm{l}^{16}$

Sebagian besar AMIU pada penelitian ini menggunakan air yang berasal dari air PDAM. Sumber air baku PDAM Kota Lhokseumawe dikelola bersama oleh Perusahaan Daerah Air Minum Mon Pase dan Kabupaten Aceh Utara. Sumber airnya berasal dari sungai/air permukaan dan air tanah. ${ }^{17}$ Sumber baku lain yang digunakan berasal dari sumber air baku PT. PIM. Sumber air baku PT. PIM diambil dari sungai Peusangan (Kabupaten Bireuen), dimana air tersebut melewati beberapa tahap pengolahan agar air baku yang dihasilkan tidak terkontaminasi oleh zat berbahaya. ${ }^{18}$

Umumnya di kota-kota besar lain seperti kota Gorontalo di Provinsi Sulawesi Selatan, perusahaan air minum mendistribusikan air yang berasal dari sungai Bone melalui jaringan pipa air, sehingga sebagian penduduk kota mengkonsumsi air yang berasal dari PDAM. Penelitian Balihristi (Badan Lingkungan Hidup, Riset, dan Teknologi) membuktikan bahwa sungai Bone telah tercemar berbagai logam berat seperti kadmium, merkuri, dan timbal akibat dari pertambangan emas ilegal yang ada di wilayah Bone Bolango. ${ }^{19}$

Data hasil penelitian ini menemukan bahwa 1 (satu) AMIU di Kecamatan Muara Satu mengandung Cd melewati ambang batas yaitu $0,004 \mathrm{mg} / 1$ dengan sumber air baku berasal dari PT. PIM. Daerah tersebut berlokasi dekat dengan industri pupuk PT. PIM. Limbah air dari industri pupuk terutama mengandung amonia, nitrat, fosfat, dan logam berat seperti $\mathrm{Cd}^{20}$ Selain itu, proses pengolahan air pada DAMIU tersebut tidak menggunakan sistem Reverse Osmosis (RO) tetapi hanya dengan sistem mikrofilter dan sistem ultra violet yang hanya mampu membunuh mikroorganisme tetapi tidak dapat menghilangkan logam-logam berat yang ada di AMIU. Sistem RO mampu mereduksi hingga 98\% logam-logam berat seperti Arsen (As) dan Kadmium (Cd) dan mampu mereduksi senyawa organik, bakteri, virus, jamur, dan kontaminasi pestisida. ${ }^{21}$ Perawatan peralatan yang digunakan juga kurang seperti tidak adanya pencucian filter secara berkala, atau pergantian mikrofilter setiap 3 bulan dapat juga mempengaruhi kualitas air minum isi ulang. ${ }^{22}$

Logam berat Cd sangat toksik bagi manusia walaupun dalam konsentrasi yang sangat rendah. Kadmium biasanya terkandung pada limbah industri dan perkotaan, sehingga peningkatan industrialisasi bertanggung jawab terhadap tingginya kadar logam berat pada perairan. ${ }^{23}$ Penelitian di India mengenai kandungan Cd dalam air tanah di 4 distrik (masingmasing diambil 6 lokasi) menunjukkan seluruh sampel yang diambil mengandung kadar $\mathrm{Cd}$ 
dengan kadar Cd tertinggi yaitu 0,07 mg/l. Kadar ini melebihi ambang batas yang diatur oleh WHO tahun 2011 yaitu $0,003 \mathrm{mg} / \mathrm{l}$. Hasil ini berkaitan dengan kondisi daerah tersebut yang padat penduduk dan distrik ini merupakan pusat industri elektronik, sehingga kemungkinan adanya pembuangan limbah ilegal. ${ }^{24}$

Beberapa penelitian telah dilakukan untuk menentukan hubungan antara lingkungan dan air minum terhadap suatu penyakit yang terjadi di masyarakat. Material terurai yang ada di sungai merupakan potensi tertinggi menyebabkan suatu penyakit. Material seperti logam berat $\mathrm{Cd}$ dapat mengendap di sedimen dasar sungai atau meresap ke dalam air tanah sehingga menyebabkan kontaminasi air tanah terutama sumur. Penelitian Naseem et al. (2014) tentang kadar Cd dalam air tanah di Kota Winder Pakistan menemukan bahwa dari 48 sampel yang diteliti hanya 29,16\% (14 sampel) air yang aman untuk dikonsumsi sesuai batasan WHO. ${ }^{25}$ Penelitian lanjutan untuk menentukan efek Cd pada Kesehatan di pemukiman daerah utara Kota Winder ini menunjukkan bahwa daerah tersebut terletak di zona batas Cd yang berlebihan. Sebanyak 9\% pasien penyakit yang berhubungan dengan ginjal dilaporkan di pemukiman ini dari total $15 \%$ responden pasien yang memiliki masalah ginjal di daerah penelitian. $^{26}$

United State Environmental Protection Agency (USEPA) melaporkan ada 13 elemen logam berat yang termasuk logam pencemar yang berbahaya, tetapi the big three heavy metal yaitu merkuri, timbal dan kadmium yang memiliki tingkat bahaya tertinggi terhadap kesehatan manusia. Hal ini karena tingkat toksisitasnya sangat tinggi walaupun dengan konsentrasi yang rendah. ${ }^{27}$ Konsumsi Cd konsentrasi rendah pada jangka waktu yang lama akan menyebabkan akumulasi di ginjal dan menyebabkan kerusakan ginjal. ${ }^{28}$

Hasil penelitian Arain et al. (2015) menunjukkan korelasi yang tinggi antara konsentrasi $\mathrm{Cd}$ di dalam darah dan urin pada pasien dengan gangguan ginjal dibandingkan dengan pasien sehat. Albuminuria, suatu keadaan adanya albumin di dalam urin merupakan biomarker klinik gangguan ginjal. Penelitian yang dilakukan di Australia bahwa kadar Cd di dalam urin berhubungan dengan albuminuria. ${ }^{29}$ Efek Cd dapat menyebabkan batuk, sakit kepala, dan muntah pada dosis rendah sedangkan pada dosis tinggi dapat menyebabkan akumulasi pada ginjal, hati, tulang. Anemia kronik juga dapat disebabkan akibat dari paparan air minum yang mengandung Cd dalam jangka waktu yang lama. ${ }^{30}$

\section{Kesimpulan}


Penelitian ini menyimpulkan bahwa rerata kadar Kadmium masih dalam batas normal, namun terdapat 1 AMIUM ( $2 \%$ dari total sampel) yang mengandung kadar Kadmium yang melebihi ambang batas menurut Permenkes RI tahun 2010.

\section{Daftar Pustaka}

1. Asmadi. Teknologi Pengolahan Air Minum. Yogyakarta: Gosyen Publishing; 2011.

2. Maulana P. Fungsi dan Manfaat Air tersedia http://.Perpustakaan.or.id. (diakses 14 April 2019). 2012;

3. Permenkes RI. Persyaratan Kualitas Air Minum. Jakarta: Permenkes RI; 2010.

4. Khaira K. Analisis Kadar Tembaga $(\mathrm{Cu})$ dan Seng $(\mathrm{Zn})$ Dalam Air Minum Isi Ulang Kemasan Galon di Kecamatan Lima Kaum Kabupaten Tanah Datar. J Sainstek IAIN Batusangkar. 2014;6(2):116-23.

5. Riset Kesehatan Dasar. Badan Penelitian Dan Pengembangan Kesehatan. Jakarta: Departemen Kesehatan; 2017.

6. Rahayu CS, Setiani O, Nurjazuli. Faktor Resiko Pencemaran Mikrobiologi pada Air Minum Isi Ulang di Kabupaten Tegal. J Kesehat Lingkung Indones. 2013;12(1):1-9.

7. Lubis H, Putra EDL, Jas A. Pemeriksaan Cemaran Bakteri dan Beberapa Logam Berat Pada Air Minum Isi Ulang Yang Beredar di Kota Medan. e J usu. 2005;38(4).

8. WHO. Guideline For Drinking Water Quality [Serial Online]. 2nd ed. Vol. 1. Geneva: World Health Organization; 1998. Diunggah dari: www.who.int

9. Akbar AW, Daud A, Mallongi A. Analisis Risiko Lingkungan Logam Berat Cadmium (Cd) Pada Sedimen Air Laut di Wilayah Pesisir Kota Makassar. 2014;(Cd):1-8.

10. Reza AH, Mehdi HN, Mehdi AM, Farham K. A Study On Leakage of Heavy Metals From The PVC And Polypropylene Pipes Used In The Water Distribution System In Isfahan. J Environtmental Res Public Heal. 2010;6(3):373.

11. Widowati W, Sastiono A, Jusuf R. Efek Toksik Logam. Yogyakarta: Andi; 2008.

12. Herman, Danny, Zulkifli. Tinjauan Terhadap Tailing Mengandung Unsur Pencemar Arsen (As), Merkuri $(\mathrm{Hg})$, Timbal (Pb), Dan Kadmium (Cd) Dari Sisa Pengolahan Bijih Logam. J Geol. 2006;1(1):31-6.

13. O'Neill P. Environmental Chemistry, Second edition, Chapman \& Hall. London; 1994. 268 p.

14. Ying Ouyang, John Higman, Jeanne Thompson, Tim O'Toole, Dean Campbell. Characterization And Spatial Distribution Of Heavy Metals In Sediment From Cedar And Ortega Rivers Subbasin. J Contam Hydrol. 2002;54(1-2):19-35.

15. Ghaemi, P., S. Rostami and AG. Determination Of Lead \& Copper In Drinking Waters In Tehran. J Envintmental Study. 2005;35:27-32.

16. Muhaimin, Ismayanti NA, Kesumaningrum F. Analisis Kadar Logam Fe, Cr, Cd dan Pb dalam Air Minum Isi Ulang Di Lingkungan Sekitar Kampus Universitas Islam Indonesia Yogyakarta Menggunakan Spektrofotometer Serapan Atom (SSA). Indones J Chem Anal. 2019;02(01):41-6.

17. Badan Perencanaan Pembangunan Daerah (BAPPEDA). Strategi sanitasi Kota Lhokseumawe [Serial Online]. 2010. Diunggah dari: http://ppsp.nawasis.info

18. Andrian, Syahrizal, Indrawan. Analisis Jaringan Sistem Air Bersih pada Kompleks Perumahan PT ARUN NGL Lhokseumawe [Skripsi]. Medan: Universitas Sumatera Utara; 2014.

19. Nurfadillah AR. Cemaran Logam Berat Dalam Air PDAM Kota Gorontalo [Skripsi]. Gorontalo: Universitas Negeri Gorontalo; 2014.

20. Bhandari V, Sorokhaibam LG, Ranade V. Industrial wastewater treatment for fertilizer industry-A case study. J Desalin Water Treat. 2016;57(57):27934-44.

21. Nuraini, Iqbal, Sabhan. Analisis Logam Berat Dalam Air Minum Isi Ulang (AMIU) Dengan Menggunakan Spektrofometri Serapan Atom (SSA). J Fis. 2015;14(1):36-41.

22. Rahayu CS, Setiani O, Nurjazuli. Faktor Risiko Pencemaran Mikrobiologi pada Air Minum Isi Ulang di Kabupaten Tegal. J Kesehat Lingkung Indones. 2013;12(1).

23. Singh S, Lal S, Harjit J, Amlathe S, Kataria HC. Potential of Metal Extractants in Determination of Trace Metals in Water Sample. J Biol. 2011;3(5):239-46.

24. Idress N, AbdAllah EF, Tabassum B, Hashem A, Sarah R, Hasim M. Groundwater Contamination With Cadmium Concentration In Some West U.P. Regions, India. Saudi J Biol Sci. 2018;25(7).

25. Naseem, Hamza, Bashir, Pirzada T, Talpur MMA. Trace Element Geochemistry of Groundwater of Winder, Balochistan, Pakistan and its Appraisal for Irrigation Water Quality. Br J Appl Sci Technol. 2013;3(1):182-98.

26. Burke F, Hamza S, Naseem S, Azama SN-HM, Khan I. Impact of Cadmium Polluted Groundwater on Human Health: Winder, Balochistan. J Sagepub. 2016; 
27. Abbas Rezaee, Jamshid Derayat, Seyed Bagher Mortazavi, Yadollah Yamini, Jafarzadeh. Removal of Mercury From Chlor-Alkali Industry Wastewater Using Acetobacter Xylinum Cellulose. Am J Environmental Sci. 2005;2(1):102-5.

28. US Department of Human and Health Services. Toxicological profile for Cadmium. 2010.

29. Arain. Co-exposure of arsenic and Cadmium through drinking water and tobacco smoking: risk assessment on kidney dysfunction. J Environ Sci Pollut Res. 2015;22(1):350-7.

30. Webb. The Geochemistry, Biochemistry And Biology of Cadmium. Amsterdam: Elsevier; 1979. 